\title{
The Factors Impacting Nurses Awareness on Prevention Healthcare-Associated Infections: A Systematic Review
}

\author{
Diah Arruum $^{1,3}$, Enie Novieastari ${ }^{2 *}(\mathbb{D})$, Dewi Gayatri ${ }^{2}$, Nur Meity Sulistia Ayu ${ }^{1}$ \\ ${ }^{1}$ Doctorate Study Program, Faculty of Nursing, Universitas Indonesia, Depok, Indonesia; ${ }^{2}$ Departement of Basic Science and \\ Fundamentals Nursing, Faculty of Nursing, Universitas Indonesia, Depok, Indonesia; ${ }^{3}$ Faculty of Nursing, Universitas Sumatera \\ Utara, Medan, Indonesia
}

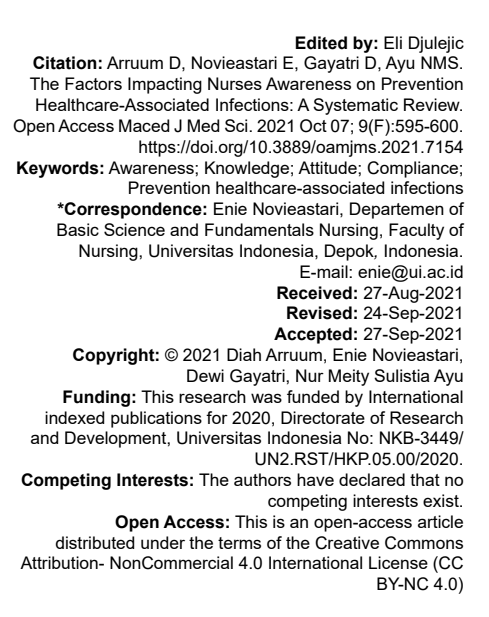

Introduction

One of the common causes of the increase in patients' mortality and morbidity rate is HealthcareAssociated Infections (HAls). Several factors lead to the occurrence of HAls, such as the use of invasive devices, poor nurse-to-patient ratio interaction, surgical procedures, ineffective programs designed to reduce $\mathrm{HAl}$, the severity of the underlying illness, and prolonged stay at the hospital [1]. According to the World Health Organization, some factors associated with the occurrence of HAls are invasive devices, insufficient equipment, overcrowding, understaffing, inadequate knowledge and use of basic infection control measures, poor safety knowledge of injection and blood transfusion, ineffective procedures, and absence of local as well as national guidelines and policies [2].

There are numerous simple and cheap infection prevention and control measures, such as hand hygiene and the use of basic health precautions techniques. However, these measures need staff accountability and behavioral change. One of the solutions to this problem is implementing standard precautions (SPs), such as best hand hygiene practices while attending to patients, improving staff education and accountability [2]. During the COVID-19 pandemic, CDC recommended using infection prevention methods with standard practices as a routine healthcare delivery to all patients. This process is conducted by wearing facemask, gloves, goggles, and washing the hands before and after coming in contact with patients [3]. However, some of the reasons associated with health worker infections during the pandemic COVID-19 are inadequate awareness and precautionary measures, patient overload, and staff burnout [4].

A urinary tract infection (UTI) is one of the most common $\mathrm{HAl}$ in developed countries, with surgical site infection is popular in one-third of the areas with limited resources. Furthermore, in developed countries, approximately, $30 \%$ of the patients in intensive care units (ICU) are affected by at least one HAI [2]. Therefore, it is important to determine HAls capable of harming patients, health workers and hospitals. Research carried out in Brazil on 3 sectors of the ICU using 1048 adults, showed that 947 patients were in the Neonatal ICU, and semi-intensive unit due to the poor compliance of nurses to the five policies of hygiene on infection prevention in the hospital. The neonatal ICU 
had a higher rate of adherence to hand hygiene when compared to other sectors [5].

In Vietnam, the staff possessed adequate knowledge, unaware of hospital infection control, including lack of resources, poor awareness, and patient overload. According to Lien, Johansson, and Lan et al. that the HAls available for health workers can improve staff awareness and put their existing knowledge into practice, thereby decreasing the know-do gap in infection control [6]. The systematic review focused on knowledge, attitude, and compliance to practice as factors impacting nurses' awareness. Furthermore, personal value (attitude, behavior), learning style (process information), and orientation toward change (environment, locus of control) are part of self-awareness areas [7]. However, irrespective of the numerous studies on Healthcare-Association Infections in hospitals, there is a gap on the right prevention strategies that need to be adopted by nurses such as knowledge, attitude, practice and compliance. Therefore, a systematic review is specifically needed to examine the factors impacting these factors to enable the proper prevention of HAls.

\section{Methods}

\section{Study design}

This study used a systematic review to address the question related to the factors impacting nurses awareness of the prevention of HAls. Therefore, the review was conducted on the ProQuest, ScienceDirect, PubMed, and Google Scholar sources of data collection. Four design studies were used to carry out the research, namely, cross-sectional, descriptive, observational, and survey. The guidelines used were the Preferred Reporting Items for Systematic Reviews and Meta-Analyses.

\section{Search strategy}

The search equations used were nurses' awareness OR knowledge OR consciousness AND nurse compliance AND adherence AND infection prevention control OR HAI. Four electronic databases were available in English from 2011 to 2020, namely ProQuest, ScienceDirect, PubMed, and Google Scholar with $n$ values of $255,120,51$, and 41 . After the duplicates were removed, 459 articles were left, with their titles and abstracts subsequently screened by two reviewers to assess the eligibility based on inclusion and exclusion criteria.

\section{Selection of studies}

The inclusion criteria were nurses as a sample population, awareness, knowledge, attitude, and compliance with prevention regulations, which consists of hand hygiene, personal protective equipment, and prevention policies on HAls. Furthermore, a questionnaire survey, direct observation, and self-reported strategies were used to obtain prevention policies.

\section{Data extraction process}

Thirteen Full-text articles were assessed for eligibility and full-texts were independently reviewed with twelve studies eligible for inclusion.

\section{Results}

\section{Type of studies}

Out of a total of 467 articles, 8 were duplicated, thereby producing 459 eligible articles. Furthermore, examining their title and abstract, 446 articles were excluded, and after full review on the remaining 13 , a total of 12 articles met the inclusion criteria as shown in Table 1. The main reason for excluding 1 the last article was because it was related to assessing the hepatitis $B$ vaccine, which exposed nurses to bloodborne pathogens and needles. The sample population was 4329 nurses that provided direct patient care in the ICU, Neonatal ICU, surgical ward, mix nursing ward and critical care unit with $n$ values of 1, 1, 3 and 7. All studies focused on preventing HAls regarding SP.

\section{Nurses knowledge and attitude on prevention HAls}

The knowledge and attitudes of nurses based on this study, had gaps and differences thereby leading to inadequate knowledge related to HAls. Out of the total number of studies, few stated that urinary and respiratory tract infections (RTIs) were the two most common HAls in the surgery ward due to higher educational levels. Therefore, nurses with a higher educational level tend to perform the right antisepsis while working on surgical wounds. They also tend to adhere to the principle of handwashing before and after medication to prevent transmitting infectious diseases. Several hospitals reported that they employed qualified HAls nurses with an adequate understanding of the guidelines for disinfection procedures and hygiene, with a more positive attitude [8].

Similar results also found that half the number of nurses understood the need to carry out preoperative hair removal, when necessary, such as shortly before surgery [9]. Lobo et al. stated that nurses have average knowledge on infection control in surgical [10]. 
Table 1: Nurses awareness on prevention HAls

\begin{tabular}{|c|c|c|c|c|c|}
\hline Author/topic & Study desain & Setting & Sample & Measurement & Results \\
\hline Goodarzi (2020) Iran & $\begin{array}{l}\text { Descriptive cross- } \\
\text { sectional using } \\
\text { questionnaire }\end{array}$ & $\begin{array}{l}\text { University of Medical } \\
\text { Sciences }\end{array}$ & 600 nurses & $\begin{array}{l}\text { Knowledge and attitude with hand } \\
\text { hygiene }\end{array}$ & $\begin{array}{l}\text { Nursing employees who participated had good } \\
\text { knowledge of hand hygiene, a neutral attitude } \\
\text { towards this practice and a high perception of it }\end{array}$ \\
\hline Lobo et al. (2019) India & $\begin{array}{l}\text { Descriptive Cross- } \\
\text { sectional, using } \\
\text { Observational }\end{array}$ & 1550 bed A. J. Hospital & 80 nurses & $\begin{array}{l}\text { Knowledge, self-report practice } \\
\text { compliance, observation infection } \\
\text { control, attitude }\end{array}$ & $\begin{array}{l}\text { Knowledge, self-report practice compliance, and } \\
\text { observation of nurses were average. The attitude } \\
\text { was positive }\end{array}$ \\
\hline Zucco et al. (2019) Italy & $\begin{array}{l}\text { Cross-sectional survey } \\
\text { using questionnaire }\end{array}$ & 36 hospital & 1305 nurses & $\begin{array}{l}\text { Knowledge, the attitudes and the } \\
\text { adherence on the Surgical Site } \\
\text { Infection (SSI) /HAls }\end{array}$ & $\begin{array}{l}\text { Nurse's knowledge and attitude needed to increase } \\
\text { as nurses just knew that pre-operative hair removal, } \\
\text { did not know the right definition of the bundle, but } \\
\text { nurses always performed hand antisepsis }\end{array}$ \\
\hline Lim et al. (2019) Korea & $\begin{array}{l}\text { Cross-sectional using } \\
\text { questionnaire }\end{array}$ & $\begin{array}{l}\text { Tertiary teaching, } \\
\text { university-affiliated } \\
\text { hospital }\end{array}$ & 329 nurses & $\begin{array}{l}\text { Adherence and perception of patient } \\
\text { safety management associated SP }\end{array}$ & Adherence of nurses was approximate \\
\hline $\begin{array}{l}\text { Gawad et al. (2017) } \\
\text { Yemen }\end{array}$ & $\begin{array}{l}\text { Cross-sectional using } \\
\text { questionnaire }\end{array}$ & $\begin{array}{l}\text { The governmental and } \\
\text { private hospitals }\end{array}$ & 196 nurses & $\begin{array}{l}\text { Knowledge of SP and infection } \\
\text { nosocomial }\end{array}$ & Nurses had poor knowledge \\
\hline Accardi et al. (2017) Italy & $\begin{array}{l}\text { Descriptive using } \\
\text { Observational }\end{array}$ & $\begin{array}{l}16 \text { ward of clinical in } \\
\text { Medicine and Surgery } \\
\text { area }\end{array}$ & 245 nurses & $\begin{array}{l}\text { Knowledge and adherence of nurses } \\
\text { to the guidelines on the HAls }\end{array}$ & $\begin{array}{l}\text { Knowledge and practice compliance of nurses has } \\
\text { sufficient level, but for hand, hygiene had good than } \\
\text { the other to prevention HAls }\end{array}$ \\
\hline Sarani et al. (2016) Iran & $\begin{array}{l}\text { Descriptive study using } \\
\text { questionnaires }\end{array}$ & Two teaching Hospital & 145 nurses & $\begin{array}{l}\text { Knowledge, attitude, and practice } \\
\text { regarding SP for HAls }\end{array}$ & $\begin{array}{l}\text { Most nurses had poor knowledge, an average } \\
\text { practice and a moderate attitude about HAI control }\end{array}$ \\
\hline $\begin{array}{l}\text { Assadollahi, et al. } \\
\text { (2015) Iran }\end{array}$ & $\begin{array}{l}\text { Descriptive cross- } \\
\text { sectional using } \\
\text { questionnaire }\end{array}$ & $\begin{array}{l}\text { NICUs affiliated } \\
\text { to Tabriz teaching } \\
\text { hospitals }\end{array}$ & 150 nurses & Knowledge regarding hand hygiene & $\begin{array}{l}\text { Most nurses had a good level of knowledge about } \\
\text { hand hygiene, but nurses had reported a need to } \\
\text { renew their training in this regard }\end{array}$ \\
\hline Sodhi et al. (2013) India & $\begin{array}{l}\text { Cross-sectional using } \\
\text { questionnaire }\end{array}$ & 350 bed Hospital & 100 nurses & $\begin{array}{l}\text { The hand hygiene, standard and } \\
\text { transmission-based precautions, } \\
\text { care bundles and general infection } \\
\text { control practices }\end{array}$ & $\begin{array}{l}\text { Knowledge and awareness were excellent, } \\
\text { including hand hygiene. but standard and } \\
\text { transmission-based precautions, care bundles and } \\
\text { general infection control practices were average }\end{array}$ \\
\hline $\begin{array}{l}\text { Darrawad et al. (2012) } \\
\text { Jordan }\end{array}$ & $\begin{array}{l}\text { Cross-sectional using } \\
\text { questionnaire }\end{array}$ & $\begin{array}{l}3 \text { hospital from } 31 \\
\text { hospital }\end{array}$ & 198 nurses & $\begin{array}{l}\text { Knowledge, attitude and compliance } \\
\text { of nurses }\end{array}$ & $\begin{array}{l}\text { The nurses showed positive attitudes, lack of } \\
\text { knowledge regarding handwashing. The awareness } \\
\text { is needed to increase compliance }\end{array}$ \\
\hline $\begin{array}{l}\text { Al-Wazzan et al. (2011) } \\
\text { Kuwait }\end{array}$ & $\begin{array}{l}\text { Cross-sectional using } \\
\text { observation and } \\
\text { questionnaire }\end{array}$ & $\begin{array}{l}\text { Public secondary care } \\
\text { hospital }\end{array}$ & 454 nurses & $\begin{array}{l}\text { To assess compliance with hand } \\
\text { hygiene among nursing staff such } \\
\text { as observed hand hygiene \& hand } \\
\text { hygiene opportunity }\end{array}$ & $\begin{array}{l}\text { Observed hand hygiene compliance among nursing } \\
\text { staff in secondary care hospitals in Kuwait was poor }\end{array}$ \\
\hline Sessa et al. (2011) Italy & $\begin{array}{l}\text { Cross-sectional using } \\
\text { questionnaire }\end{array}$ & Hospital & 527 nurses & $\begin{array}{l}\text { Knowledge, attitude, and practices } \\
\text { regarding disinfection procedures }\end{array}$ & $\begin{array}{l}\text { Nurses' knowledge related to HAls was poor. } \\
\text { Nurses having positiveness attitude }\end{array}$ \\
\hline
\end{tabular}

HAls: Healthcare-Associated Infections, NICU: Neonatal intensive care units, SP. Standard precaution.

Other studies revealed that the nurses possess inadequate knowledge on the SPs on nosocomial infections in surgical and emergency wards [11]. Hand hygiene precautions are related to the avoidance of needlestick injuries were related to the essential level of knowledge. Meanwhile, the lowest level of knowledge was related to precautions such as proper techniques used to wear gowns, masks, gloves and glasses during clinical procedures in internal medicine, pediatric, dialysis and surgical ward [12].

Furthermore, half of the nursing employees participating, in the study, had good knowledge of hand hygiene in ICU [13]. This was similar to the study carried out by [14], which showed positive attitudes regarding nurses' adherence to handwashing. The results of research by Accardi stated that nurses possess sufficient levels of knowledge regarding guidelines of HAls which is associated with cleaning, disinfection, sterilization, to prevent character-related Bloodstream Infections (BSI), SSI, RTI, and UTI [15].

Some studies also showed excellent precaution on nurses' knowledge using obesity as a risk factor for surgical site infection [9], Nurses need to possess adequate knowledge of infection control [16], [17], and self-rated hand hygiene [18]. The majority of the participants have an excellent level of knowledge regarding hand hygiene, with the lowest score associated with the definition of its domain [17]. The overall knowledge of nurses on the different infection control practices was excellent. However, Sodhi et al. stated that other infection control practices include care bundles, standard and transmission-based precautions, and general infection control practices [16]. Nurses' practice compliance on Prevention HAls The non-compliance of nurses in preventing HAls was also reported in many studies. This is because their practice to SPs HAls was low for those working in surgical, medical, and ICU wards. This includes their inability to wear a mask, goggles, face shield, gown, apron, decontaminate hand after removal of gloves, hand wash/rub between patient contacts, and disposal of boxes filled with sharp objects [19]. According to Zucco et al., gloves need to be worn during this practice to prevent surgical site infection [9]. The study carried out by Sarani et al. stated that nurses have an average practice of HAls control [12], based on self-reported

Al-Wazzan et al. reported that nurses washed their hands before wearing gloves, and measuring the blood pressure of patients [18]. They also washed their hands before and after work. Handwashing is important due to its ability to stop the spread of infections [14]. Lim et al. stated that nurses practiced compliance by putting sharp objects into boxes [19].

According to Zucco et al. that nurses adhere to the use of hand antisepsis before and after invasive procedures and always reported the utilization of singleuse protective equipment in patients with infectious diseases [9]. After coming in contact with patients, their fluids or instruments, they are expected to thoroughly disinfect their bodies to prevent the transmission of HAls [14]. The other results related to nurses' compliance to HAls regulations found that the ability 
to clean, disinfect and sterilize clinical equipment was important to prevent SSIs, RTIs, UTIs, and catheterrelated to $\mathrm{BSI}[15]$.

\section{Nurses' awareness is based on knowledge and practice on the prevention of HAls}

The nurses having low awareness in washing hand. According to Sodhi et al. that the awareness of nursing staff on different infection control practices, such as hand hygiene, was not sufficient [16]. Therefore, information on transmission-based precautions, and general infection control practices are needed to protect patients from contracting HAls. Therefore, nurses need to possess adequate knowledge of infection control guidelines and compliance with handwashing. They also need to possess adequate knowledge of removing gloves, washing hands after various activities, and practice hand hygiene [18].

\section{Discussion}

This study research was carried out to determine the nurses' awareness of the various strategies needed for the prevention of HAls. This determines the suboptimal knowledge of nurses regarding HAls, although some had good knowledge; however, almost all nurses in the prevention of HAls were a positive attitude. Regarding knowledge of Infection Control Precautions (ICPs) revealed that nurses had low levels of knowledge, with higher positive attitudes toward ICPs in the medical, surgical, ICUs, pediatric ward, and emergency units in Jordan [20]. In another study carried out in Nigeria, nurses had poor knowledge of injection safety, which few were aware of the dangers associated with recapping sharp objects, and the disadvantages of bending or breaking sharps or needles. However, they had adequate knowledge of hand hygiene, such as washing hands before and after touching a patient and wearing gloves before venipuncture [21].

This study also described that nurses had low practice compliance on the prevention of HAls, as well as a lack of guidelines, SP, and inconsistency in policies and practices in the healthcare setting. Furthermore, the study carried out in Nigeria showed that few the Health Care Workers (HCWs) are aware of the guidelines/protocols for infection control, by wearing a mask and gown before entering the ICU [22]. Other studies carried out on compliance with SPs among the HCWs in Ethiopia showed that nurses' knowledge on HAls is very low [23]. A similar study carried out in Nigeria showed that nurses adhered to the health safety policies; however, there were inadequate resources to practice SPs such as hand hygiene, injection safety, and handling sharps objects [21]. Regarding compliance to policies, nurses scored higher grades than ICPs [20]. Nurses tend to comply with hand hygiene, such as washing their hands when dirty or after coming in contact with patient's body fluids. Burnett stated that higher compliance was associated with hand hygiene using alcohol-based disinfectants [24]. The overall knowledge, attitude, and compliance showed that lack of knowledge and inadequate practice affected. Sarani et al. stated that nurses with more knowledge of infection control had better practice [12].

In general, deficiency in the knowledge was observed; the nurses provided average or below-average responses to other infection control practices. The research in Nigeria indicated that HCWs adhered poorly to the hygiene policies [22]. There was contradiction among these factors in SPs of HAls in the nursing area due to lack of awareness, thereby leading to poor knowledge, attitude, and practice. Nevertheless, supervision on the precaution against infection is indispensable. Although nurses possess adequate knowledge and received training, supervision and feedback are needed for sustainability and to prevent infection. Storr et al. stated that the monitoring and feedback of infection control practices are needed to demonstrate existing gaps and possess behavioral change toward good practices [25]. Three studies related to the surgical ward stated that the majority failed to comply with the policy. Other studies stated that HCWs were not aware of the HAls situation and own role in preventing it from avoiding infections, RTIs, and HIV through the use of unsterilized needles. Their inabilities to detect these infections were due to poor awareness of hospital staff, lack of facilities, insufficient equipment and supplies, as well as a patient overload [6]. However, the results of research from Rizk, EL-Raghi, and Zein found that although the availability of adequate facilities, based on observations time, the implementation of handwashing is still low, where only $10 \%$ of the 20 nurses wash hands [26]. Therefore, efforts are needed to improve awareness of staff hospitals by providing alcohol-based hand rub solutions, carrying out annual training on infection control, and availability of standard protocols [6]. Support from management is very important in increasing motivation to wash hands.

The results of the study from Shahrbabaki, et al. stated that the workload, lack of knowledge and wrong behavior patterns and not yet optimal management such as planning, training, and lack of availability of equipment were obstacles to handwashing for health workers including nurses in the Intensive Care room, have not awareness in preventing infection which can result in increased costs [27]. In line with research from Daulay, Sudiro, dan Amirah that in supporting the implementation of handwashing, it is necessary to contribute from management, namely supervision and providing training, so that $45.3 \%$ of infection control management is in the insufficient category [28]. 
Based on the 12 articles found, the most problems in handwashing were in the intensive care room and implementation of supervision from managers and continuous training is needed.

Educational programs are also needed to improve awareness of universal protocol for the prevention of HAls [22]. The studies in the twelve selected articles indicated that the education program for nurses was needed. This is supported by the result of the study that perception of training on SP, accessibility of PPE, and management support, which are statistically significant [23], and they were the most essential participants with knowledge on hand hygiene [17].

Based on the results obtained from hospitals in Vietnam, no staff received education on infection control [6]. Approximately, $56.8 \%$ of the nurses attended a training course on ICPs [20].

Education and training program for nurses in health care centers is essential, therefore, when conducted continuously, it becomes a critical unit of care. Conversely, studies with guidelines and practices had lower compliance. Storr et al. stated that the education and training program needs to be undertaken to achieve successful implementation of the guidelines with HWCs [25]. Almost all of the study in this systematical review was conducted in critical care, such as ICU, Neonatal ICUs, emergency, surgery and pediatric wards. According to the study, lack of knowledge and low level of practice compliance were the causes of poor infection prevention, particularly in intensive/critical units. The research indicates that nurses lacked awareness and this means that they have problems with personal value, (attitude, behavior), learning style (process information), and orientation toward change (environment, locus of control). This led to the provision of guidelines, which was ignored by almost all nurses. Therefore, supervision or direct observations need to be conducted by managers to increase awareness.

\section{Conclusion}

Nurses had low levels of knowledge with higher positive attitudes and low level of practice compliance. Knowledge, attitude, and practice compliance to guidelines on the prevention of HAls are an indication of nurses' awareness in hospitals. Therefore, a SP that is important to patient safety management was given a high priority. Nurses' training education program to prevent HAls such as hand hygiene, wearing personal protective equipment, direct observation and for which targeted activities are needed and support nurse managers or supervisor to implement on prevention HAls focused at enabling to increase awareness.

\section{Acknowledgments}

The authors are grateful to the University of Indonesia Rector and Dean of nursing faculty.

\section{References}

1. Al-Tawfiq JA, Tambyah PA. Healthcare associated infections (HAI) perspectives. J Infect Public Health. 2014;7(4):339-44. http://doi.org/10.1016/j.jiph.2014.04.003

PMid:24861643

2. World Health Organization. Health Care-associated Infections Fact Sheet. Geneva: World Health Organization; 2014. p. 1-4.

3. Control, Center for Disease and Prevention C. Interim Infection Prevention and Control Recommendations for Healthcare Personnel During the Coronavirus Disease 2019 (COVID-19) Pandemic; 2020

4. Ye L, Yang S, Liu C. Infection prevention and control in nursing severe coronavirus disease (COVID-19) patients during the pandemic. Crit Care. 2020;24(1):338. http://doi.org/10.1186/ s13054-020-03076-1

PMid:32532324

5. Bezerra TB, Valim MD, Bortolini J, Ribeiro RP, Marcon SR Moura ME. Adherence to hand hygiene in critical sectors: Can we go on like this? J Clin Nurs. 2020;29:2691-8. http://doi. org/10.1111/jocn.15293

PMid:32301162

6. Lien LT, Johansson E, Lan PT, Chuc TK, Thoa NT, Hoa NQ, et al. A potential way to decrease the know-do gap in hospital infection control in Vietnam: Providing specific figures on healthcare-associated infections to the hospital staff can "wake them up" to change their behaviour. Int J Environ Res Public Health. 2018;15(7):1549. http://doi.org/10.3390/ijerph15071549 PMid:30037135

7. Whetten DA, Cameron KS. Developing management skills $8^{\text {th }}$ ed. Yagan S, Svendsen E, Norbuta CF, editors. Management Learning. New Jersey: Pearson; 2011. p. 1-713.

8. Sessa A, Di Giuseppe G, Albano L, Angelillo IF. An investigation of nurses' knowledge, attitudes, and practices regarding disinfection procedures in Italy. BMC Infect Dis. 2011;11:148. http://doi.org/10.1186/1471-2334-11-148

PMid:21612613

9. Zucco R, Lavano F, Nobile CG, Papadopoli R, Bianco A. Adherence to evidence-based recommendations for surgical site infection prevention: Results among Italian surgical ward nurses. PLoS One 2019;14(9):e0222825. http://doi.org/10.1371/ journal.pone.0222825 PMid:31557219

10. Lobo D, Sams L, Fernandez S. Correlation between health professionals knowledge, attitude and practice about infection control measures. J Med Allied Sci. 2019;9(1):26.

11. Gawad A. Assessment of knowledge about standard precautions and nosocomial infection among nurses working in hospitals of Sana'a City, Yemen. J Caring Sci Int 2017;10(1):169-75.

12. Sarani H, Balouchi A, Masinaeinezhad N, Ebrahimitabas E. Knowledge, attitude and practice of nurses about standard precautions for hospital-acquired infection in teaching hospitals affiliated to Zabol university of medical sciences (2014). Glob J Health Sci. 2016;8(3):193-8. http://doi.org/10.5539/gjhs. v8n3p193 


\section{PMid:26493432}

13. Goodarzi Z, Haghani S, Rezazade E, Abdolalizade M Khachian A. Investigating the knowledge, attitude and perception of hand hygiene of nursing employees working in intensive care units of Iran University of Medical Sciences, 2018-2019. Maedica (Bucur). 2020;15(2):230-7. http://doi.org/10.26574/ maedica.2020.15.2.230

\section{PMid:32952688}

14. Darawad MW, Al-Hussami M, Almhairat II, Al-Sutari M. Investigating Jordanian nurses' handwashing beliefs, attitudes, and compliance. Am J Infect Control. 2012;40(7):643-7. http:// doi.org/10.1016/j.ajic.2011.08.018

PMid:22245246

15. Accardi R, Castaldi S, Marzullo A, Ronchi S, Laquintana D, Lusignani M. Prevention of healthcare associated infections: A descriptive study. Ann Ig. 2017;29(2):101-15. http://doi. org/10.7416/ai.2017.2137 PMid:28244579

16. Sodhi K, Shrivastava A, Arya M, Kumar M. Knowledge of infection control practices among intensive care nurses in a tertiary care hospital. J Infect Public Health. 2013;6(4):269-75. http://doi.org/10.1016/j.jiph.2013.02.004 PMid:23806701

17. Asadollahi $M$, Bostanabad MA, Jebraili $M$, Mahallei $M$, Rasooli AS, Abdolalipour M. Nurses' knowledge regarding hand hygiene and its individual and organizational predictors. J Caring Sci. 2015;4(1):45-53. http://doi.org/10.5681/jcs.2015.005 PMid:25821758

18. Al-Wazzan B, Salmeen Y, Al-Amiri E, Abul A, Bouhaimed M, Al-Taiar A. Hand hygiene practices among nursing staff in public secondary care Hospitals in Kuwait: Self-report and direct observation. Med Princ Pract. 2011;20(4):326-31. http://doi. org/10.1159/000324545 PMid:21576991

19. Lim JH, Ahn JW, Son YJ. Association between hospital nurses perception of patient safety management and standard precaution adherence: A cross-sectional study. Int J Environ Res Public Health. 2019;16(23):4744. http://doi.org/10.3390/ ijerph16234744 PMid:31783559

20. Nofal $M$, Subih $M$, Al-Kalaldeh $M$. Factors influencing compliance to the infection control precautions among nurses and physicians in Jordan: A cross-sectional study. J Infect Prev.
2017;18(4):182-8. http://doi.org/10.1177/1757177417693676 PMid:28989525

21. Ogoina D, Pondei K, Adetunji B, Chima G, Isichei C, Gidado S. Knowledge, attitude and practice of standard precautions of infection control by hospital workers in two tertiary hospitals in Nigeria. J Infect Prev. 2015;16(1):16-22. http://doi. org/10.1177/1757177414558957 PMid:28989394

22. Adegboye MB, Zakari S, Ahmed BA, Olufemi GH. Knowledge, awareness and practice of infection control by health care workers in the intensive care units of a tertiary hospital in Nigeria. Afr Health Sci. 2018;18(1):72-8. http://doi.org/10.4314/ ahs.v18i1.11

PMid:29977260

23. Haile TG, Engeda EH, Abdo AA. Compliance with standard precautions and associated factors among healthcare workers in gondar university comprehensive specialized hospital, Northwest Ethiopia. J Environ Public Health. 2017;2017:2050635. http://doi.org/10.1155/2017/2050635 PMid:28191020

24. Burnett E. Effective infection prevention and control: The nurse' s role. Nurs Stand. 2018;33(4):68-73. http:// doi.org/10.7748/ns.2018.e11171 PMid:29972291

25. Storr J, Twyman A, Zingg W, Damani N, Kilpatrick C, Reilly J, et al. Core components for effective infection prevention and control programmes: New WHO evidence-based recommendations. Antimicrob Resist Infect Control. 2017;6(1):6. http://doi. org/10.1186/s13756-016-0149-9 PMid:28078082

26. Rizk HII, El-Raghi HA, Zein MM. Assessment of infection control measures at primary health care facilities in Egypt. Maced $J$ Med Sci. 2021;9:629-33

27. Shahrbabaki PM, Mahlagha D, Ahmadinejad M, Jabarpour M, Mazallahi M. Barriers to Hand Hygiene Compliance in Intensive Care Units From the Perspective of Healthcare Workers: A Qualitative Study Research; 2021. p. 1-15. Available from: https://www.researchsquare.com/article/rs-258249/latest. pdf [Last accessed on 2021 Jul 31]

28. Daulay FC, Sudiro S, Amirah A. Management analysis of infection prevention: Nurses' compliance in implementing hand hygiene in the inventories of rantauprapat hospital. J Sci Res Med Biol Sci. 2021;2(1):42-9. 